\title{
Effect of glucanases of Bacteroides oralis Ig4a on artificial plaque of Streptococcus mutans
}

\author{
Nobuyoshi Takahashi*, Takahiro Horikawa**, Fumiko Mizuno***, \\ Ayako Yamamoto*** and Kenshiro Takamori*** \\ * Department of Oral Bacteriology, School of Dentistry, Tokyo Medical and Dental University, \\ Yushima 1, Bunkyo-ku, Tokyo 113, Japan \\ ** Dokkyo University School of Medicine, \\ Mibu-machi, Shimotsuga-gun, Tochigi 321-02, Japan \\ *** Department of Oral Microbiology, School of Dentistry, Showa University, \\ Hatanodai 1, Shinagazwa-ku, Tokyo 142, Japan
}

[Accepted for publication: October 20,1982]

Key words: Bacteroides oralis / dextranase / mutanase / artificial plaque / Streptococcus mutans

Extracellular water-insoluble glucan (mu$\tan )$ has an important role in the colonization of Streptococcus mutans and in the deposition of dental plaque. Many reports have been published on the effects of glucan hydrolyzing enzymes, including dextranases and mutanases, to remove plaque from tooth surfaces. Among them, dextranases have been reported as showing little effect on removal of the plaque in vivo ${ }^{1-5)}$. Treatment of the plaque with purified mutanase $[\alpha-(1,3)$ glucanase] extracted from several kinds of fungi also had only a slight effect on decreasing the plaque in vivo ${ }^{6,7)}$, and in vitro ${ }^{8)}$, while Guggenheim et al. observed the effects of mutanase on rat caries and plaque ${ }^{9}$. Since mutan is the glucan containing $\alpha$ $(1,3)$ - and $\alpha$ - $(1,6)$-glucoside linkage in various percentages, both dextranase and mutanase should be required for hydrolyzing it. In this connection, we also studied the crude enzymes of an oral bacteria, Bacteroides oralis Ig4a. This organism was isolated from human dental plaque and hydrolyzed with mu$\tan$ as well as dextran. The conclusion was that it produced both $\alpha$ - $(1,3)$-glucanase as well as $\alpha$ - $(1,6)$-glucanase ${ }^{10)}$. In this report, we confirmed that the homogenized bacterial suspension and the enzymes of $B$. oralis were effective in removing the deposits of Streptococcus mutans from the glass surface.

The bacterial strains used in this experiment were Bacteroides oralis Ig4a and Bac- teroides fragilis \#4. The latter, isolated from rat dental plaque, produced dextranase but no mutanase. The organisms were cultured in Trypticase soy broth supplemented with $0.2 \%$ dextran (Pharmacia, T-2000) under anaerobic conditions. The cell suspension, obtained by centrifugation and washing with $20 \mathrm{mM}$ phosphate buffer $\mathrm{pH} 6.5$, was homogenized with sonication at $100 \mathrm{~W}$ for $10 \mathrm{~min}$. The dextranase was extracted by the method reported previously'11). Mutanase was extracted from the cells of a batch culture of $B$. oralis Ig4a as follows: The cells were collected by centrifugation at $8,000 \times \mathrm{g}$ for $20 \mathrm{~min}$, washed twice with $20 \mathrm{mM}$ phosphate buffer $\mathrm{pH} 6.5$, and suspended in a small volume of the same buffer. The cell suspension was mixed with an equal volume of butanol and kept at $4^{\circ} \mathrm{C}$ for $30 \mathrm{~min}$. The aqueous layer was obtained by centrifugation at $20,000 \times \mathrm{g}$ for $30 \mathrm{~min}$. To the aqueous layer was added cold acetone $\left(-20^{\circ} \mathrm{C}\right)$ to a final concentration of $50 \%(\mathrm{v} / \mathrm{v})$, and kept at $-10^{\circ} \mathrm{C}$ for $20 \mathrm{hr}$. The suspension was centrifuged at $10,000 \times \mathrm{g}$ for $30 \mathrm{~min}$ and the precipitate was washed twice with cold acetone and dissolved in $20 \mathrm{mM}$ phosphate buffer. Further purification of the preparation was performed by chromatography of DEAEcellulose followed by that of phospho-cellulose. The purity of the final preparation was checked by detecting a single band on the SDS-PAGE. (Details of the methods and 


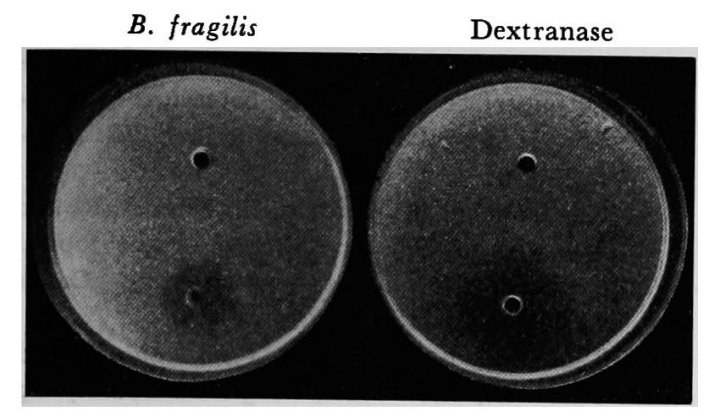

Fig. 1 Hydrolyzation of pseudonigeran by homogenized cell suspension of $B$. fragilis \#4 and $B$. oralis $\operatorname{Ig} 4$ a (left), and dextranase and mutanase of $B$. oralis Ig4a (right).

properties of the enzyme will be published.) Pseudonigeran was extracted from the mycelium of Aspergillus niger ATCC 16888 by the method of Hasegawa et al. ${ }^{12)}$.

Trypticase soy agar supplemented with pseudonigeran at a final concentration of $0.5 \%$ was prepared, and small wells were made in the agar. Fifty $\mu \mathrm{l}$ each of the disintegrated cell suspension $(20 \mathrm{mg} / \mathrm{ml})$ of $B$. oralis Ig4a or $B$. fragilis \#4, a dextranase, or mutanase $\left(200 \mathrm{U} / \mathrm{ml}^{*}\right)$ was placed in the wells, and incubated at $37^{\circ} \mathrm{C}$ for $24 \mathrm{hr}$. As shown in Fig. 1, the homogenates of $B$. oralis and the mutanase hydrolyzed the pseudonigeran showing a clear zone around the well while the homogenates of $B$. fragilis and the dextranase did not.

Streptococcus mutans GS-5 was incubated in test-tubes containing Trypticase soy broth supplemented with 5\% sucrose. After 48 hours' incubation, the culture medium was removed and the bacterial film adhering to the glass surface was washed with sterilized saline. A fresh medium containing the homogenized cell suspension $(50 \mathrm{mg} / \mathrm{ml})$ of either $B$. oralis or $B$. fragilis, or the enzyme (s) $(100 \mathrm{U} / \mathrm{ml})$ was poured into the test-tubes and incubated at $37^{\circ} \mathrm{C}$. The effect on removal of the film from the glass surface was

\footnotetext{
* The unit of enzyme activity was defined as the amount of a enzyme which released $1 \mathrm{mmol}$ of reducing sugar per minute under standard conditions described in reference 11 .
}

Table 1 Effect of homogenized cell suspension and glucanase(s) of $B$. oralis $\operatorname{Ig} 4 \mathrm{a}$ and $B$. fragilis $\# 4$ on removal of the film of $S$. mutans on glass surface ${ }^{1)}$

\begin{tabular}{lc}
\hline & $\begin{array}{c}\text { Removal } \\
\text { of film }\end{array}$ \\
\hline $\mathrm{TSB}^{2)}+$ B. oralis $\mathrm{Ig} 4 \mathrm{a}^{3)}$ & + \\
$\mathrm{TSB}+$ B. fragilis $\sharp 4^{3)}$ & - \\
$\mathrm{TSB}+$ Dextranase & - \\
$\mathrm{TSB}+$ Mutanase & - \\
$\mathrm{TSB}+$ Dextranase \& Mutanase & + \\
$\mathrm{TSB}$ & - \\
\hline
\end{tabular}

1) The film of $S$. mutans GS-5 was performed by incubation in TSB supplemented with $5 \%$ sucrose.

2) Trypticase soy broth.

3) The bacterial cells were homogenized by sonication (see the text).

determined after 2 to 20 hours incubation. The results are shown in Table 1. The homogenized suspension of $B$. oralis Ig4a showed significant activity for removing the streptococcal film within $2 \mathrm{~h}$, while the suspension of $B$. fragilis \#4 showed no activity. Either the dextranase or the mutanase had no effect on the streptococcal film when used individually. However, when both enzymes were added to the medium, a significant effect on the film was observed. These results confirmed that the combined activity of dextranase and mutanase are required for decreasing the accumulation of $S$. mutans and also indicated that the activity may be effective in removing matured dental plaque in vivo. Since $B$. oralis is a normal inhabitant of the human oral cavity, it may have a role in the ecology of the dental plaque.

\section{References}

1) Bowen, W. H.: Effects of dextranase on cariogenic and non-cariogenic dextrans. Brit. Dent. J. 124: 347-349, 1969.

2) König, K. G. and Guggenheim, B.: In vivo effects of dextranase on plaque and caries. Helv. Odont. Acta, 12: 48-55, 1968.

3) Guggenheim, B., König, K. G., Mühlemann, H. R. and Regolati, B.: Effect of dextranase on caries in rats harbouring an indigenous 
cariogenic bacterial flora. Archs. oral Biol. 14: 555-558, 1969.

4) Block, P. L., Dooley, C. L. and Howe, E. E.: The retardation of spontaneous periodontal disease and the prevention of caries in hamsters with dextranase. J. Periodontol. 40: 105-110, 1969.

5) Caldwell, R. C., Sandham, H. J., Mann, W. V., Finn, S. B. and Formicola, A. J.: The effect of a dextranase mouth wash on dental plaque in young adults and children. J. Amer. Dent. Assoc. 82: 124-131, 1971.

6) Guggenheim, B., Regolati, B. and Mühlemann, H. R.: Caries and plaque inhibition by mutanase in rats. Caries Res. 6: 289297, 1972.

7) Kelstrup, J., Funder-Nielsen, T. D. and Møller, E. N.: Enzymatic reduction of the colonization of Streptococcus mutans in human dental plaque. Acta Odont. Scand. 31: 249-253, 1973.

8) Takahara, T. and Incue, M.: Inhibitory ef- fects of endo- $\alpha-1,3$-glucanase on glucan film formation and glucan synthesis by the glucosyltransferase of the oral bacterium Streptococcus mutans. Archs. oral Biol. 26: 217222, 1981.

9) Guggenheim, B., Regolati, B., Schmid, R. and Mühlemann, H. R.: Effects of the topical application of mutanase on rat caries. Caries Res. 14: 128-135, 1980.

10) Takahashi, N., Horikawa, T., Mizuno, F. and Takamori, K.: Insoluble glucan hydrolyzing enzymes from oral Bacteroides. Bull. Tokyo Med. Dent. Univ, 27: 79-88, 1980.

11) Takahashi, N.: Isolation and properties of dextranases from Bacteroides oralis $\mathrm{Ig} 4 \mathrm{a}$. Microbiol. Immunol. 26: 375-386, 1982.

12) Hasegawa, S., Nordin, J. H. and Kirkwood, S.: Enzymes that hydrolyze fungal cell wall polysaccharides. I. Purification and properties of an endo- $\alpha$-D- $(1 \rightarrow 3)$-glucanase from Trichoderma viridae. J. Biol. Chem. 244: 54605470, 1969. 